\title{
Use of a long-acting gonadotrophin-releasing hormone analogue in a postmenopausal woman with hyperandrogenism due to a hilus cell tumour
}

\author{
M José Picón ${ }^{1}$, José Ignacio Lara ${ }^{1}$, José Luis Sarasa ${ }^{2}$, Joaquín Díaz Recasens ${ }^{3}$, Rosa Clouet $^{2}$, \\ $\mathrm{M}$ Angeles Gonzalo ${ }^{1}$ and Adela Rovira ${ }^{1}$ \\ Departments of ${ }^{1}$ Endocrinology, ${ }^{2}$ Pathology and ${ }^{3}$ Obstetrics and Gynaecology, Fundación Jiménez Díaz, Universidad Autónoma de Madrid, \\ Madrid, Spain \\ (Correspondence should be addressed to A Rovira, Department of Endocrinology, Fundación Jiménez Díaz, Avda. Reyes Católicos, 2, \\ 28040 Madrid, Spain; Email: arovira@uni.fjd.es)
}

\begin{abstract}
Objective: The aim of this study was to prove the utility of GnRH analogues for the suppression of androgen secretion in a postmenopausal woman with a suspected virilizing ovarian tumour.

Design and Methods: We present a case of a 72-year-old woman with virilization of recent onset. Hormonal studies revealed a fourfold increase in serum testosterone levels, normal dehydroepiandrosterone sulphate concentrations and high levels of serum 17-hydroxyprogesterone levels. Computed axial tomography scan of the ovaries was normal and the adrenal glands showed a discrete enlargement. The long-acting GnRH analogue, triptorelin, was injected initially (3.75 mg i.m.) and serum hormone levels were measured weekly throughout one month.

Results: GnRH produced a decrease in serum testosterone levels to normal values, in parallel with the suppression of serum LH and FSH concentrations. The patient was treated for three months with triptorelin and she experienced an amelioration of the hyperandrogenic symptoms. In order to achieve a diagnosis, the patient was submitted to a laparotomy that revealed a small hilus cell tumour in the left ovary.

Conclusion: GnRH analogues may offer a good therapeutic option in some states of gonadotrophindependent hyperandrogenism of ovarian origin.
\end{abstract}

European Journal of Endocrinology 142 619-622

\section{Introduction}

It has been reported that the secretion of androgens by some ovarian tumours can be inhibited by gonadotrophin-releasing hormone $(\mathrm{GnRH})$ agonists. Different types of testosterone-secreting ovarian tumours showing this kind of hormonal regulation, i.e. Leydig cell tumour, granulosa cell tumour, Sertoli-Leydig cell tumour, hilus cell tumour and stromal luteoma (1-5) have been described. The suppressive effect of GnRH analogues on the secretion of testosterone by the ovarian tumour cells seems to be related to an inhibition of endogenous gonadotrophin secretion.

We report the case of a postmenopausal woman with virilization of recent onset whose high serum androgen levels were normalized after the administration of the long-acting GnRH analogue, triptorelin. Follicle-stimulating hormone (FSH) and luteinizing hormone (LH) serum levels were both in the low range of postmenopausal values, and were suppressed by the GnRH agonist. Her symptoms ameliorated following triptorelin administration for three months. A bilateral oophorectomy was performed and a benign hilus cell tumour was found in the left ovary. The patient also presented a non-classic deficiency of 21-hydroxylase.

\section{Case report}

A 72-year-old postmenopausal woman, gravida 15 , para 7 , was referred to our outpatient clinic for evaluation of hirsutism. Her past medical history was remarkable for hypertension diagnosed three years ago that was well controlled with a $\mathrm{Ca}^{2+}$ antagonist. Menarche had occurred at the age of 13 years with regular monthly cycles until the cessation of menses at the age of 52 years. The patient complained of a three- to four-year history of progressive hirsutism affecting the body, arms and legs, but predominantly facial, requiring regular shaving. She had noted a 
Table 1 Hormone values in the basal situation, after the i.m. administration of $3.75 \mathrm{mg} \mathrm{GnRH}$ analogue, triptorelin, and after the removal of the tumour.

\begin{tabular}{|c|c|c|c|c|c|c|c|c|}
\hline \multirow[b]{2}{*}{ Hormone } & \multirow[b]{2}{*}{ Basal } & \multicolumn{5}{|c|}{ After GnRH analogue } & \multirow{2}{*}{$\begin{array}{l}\text { After } \\
\text { surgery }\end{array}$} & \multirow{2}{*}{$\begin{array}{c}\text { Reference } \\
\text { range }^{*}\end{array}$} \\
\hline & & 1 week & 2 weeks & 3 weeks & 4 weeks & 8 weeks & & \\
\hline DHEAS $(\mu \mathrm{mol} / \mathrm{l})$ & 2.6 & 2.6 & 2.5 & 1.8 & 2.0 & 3.1 & 2.0 & $0.2-2.6$ \\
\hline 17-Hydroxyprogesterone $(\mathrm{nmol} / \mathrm{l})$ & 4.2 & 4.8 & 3.9 & 2.1 & 2.7 & 3.6 & 3.9 & $<3$ \\
\hline Oestradiol (pmol/l) & 311 & 318 & 248 & 244 & 178 & 167 & 248 & $<93$ \\
\hline Total testosterone $(\mathrm{nmol} / \mathrm{l})$ & 11.6 & 15.1 & 2.7 & 1.3 & 1.5 & 11.6 & 1.5 & $<3.5$ \\
\hline Free testosterone (pmol/l) & 64.4 & 39.9 & 7 & 3.5 & 3.9 & 51.8 & 14.7 & $7-17.5$ \\
\hline Androstenedione (nmol/l) & 11.6 & 11.2 & 5.6 & 3.5 & 4.2 & 8.9 & & $3.5-14$ \\
\hline $\mathrm{FSH}(\mathrm{U} / \mathrm{L})$ & 24.4 & 4.4 & 1.7 & 1.3 & 1.3 & 23.9 & 29.1 & $25-145$ \\
\hline $\mathrm{LH}(\mathrm{U} / \mathrm{L})$ & 12.2 & 7.8 & 3.2 & 1.2 & 0.4 & 19.4 & 25.4 & $17-71$ \\
\hline
\end{tabular}

* Reference values are for postmenopausal women.

diffuse hair loss, acne and weight increase. She noted neither voice deepening nor a change in libido. Medical history did not reveal any medication in the past five years that might have contributed to the virilization.

The initial physical examination revealed signs of virilization such as beard, masculine alopecia and a male distribution of pubic hair. The clitoris was enlarged and no pelvic mass was palpable; her weight was $88.3 \mathrm{~kg}$, height $153 \mathrm{~cm}$, and body mass index $35.8 \mathrm{~kg} / \mathrm{m}^{2}$. Her obesity was central without striae and no goiter was palpable. The gynaecological examination disclosed a normal uterus.

Laboratory data on examination, shown in Table 1, revealed high serum levels of total and free testosterone, oestradiol and 17-hydroxyprogesterone; androstenedione and dehydroepiandrosterone sulphate (DHEAS) were in the normal range. LH was in the premenopausal follicular phase and FSH was in the low range for a menopausal woman. Cushing's syndrome was ruled out by an overnight dexamethasone suppression test $(1 \mathrm{mg})$; the basal serum cortisol level was $400 \mathrm{nmol} / \mathrm{l}$ and this decreased to $44.2 \mathrm{nmol} / \mathrm{l}$ at $08.00 \mathrm{~h}$ on the following day. Basal serum 17-hydroxyprogesterone level was $4.2 \mathrm{nmol} / \mathrm{l}$ and increased to $47.7 \mathrm{nmol} / \mathrm{l}$ after the intravenous administration of synthetic adrenocorticotrophin (ACTH) $(250 \mu \mathrm{g}$ cosyntropin). Transvaginal ultrasonography of the ovaries and the uterus was normal, the endometrium was atrophic $(4 \mathrm{~mm})$, and the CT scan of the pelvis and abdomen disclosed normal ovaries and discrete enlargement of both adrenal glands, but without masses.

Under the suspicion of hyperandrogenism of ovarian origin and in order to ascertain whether it was influenced by gonadotrophin secretion, a test with the GnRH analogue, triptorelin, was performed. Hormone levels were measured in blood collected before and at $7,14,21$ and 28 days after the intramuscular administration of triptorelin $(3.75 \mathrm{mg})$; blood was also obtained two months after the analogue injection. Results are shown in Table 1. Serum levels of testosterone decreased to normal values by the second week of the test, remaining low until the fourth week. This effect paralleled the decrease in plasma gonadotrophin levels. Serum levels of oestradiol, androstenedione, DHEAS and 17-hydroxyprogesterone also decreased. Serum gonadotrophins, testosterone, DHEAS, 17-hydroxyprogesterone and androstenedione rose to basal values two months after triptorelin administration.

The gonadotrophin dependence of the hyperandrogenism in the patient suggested an ovarian disorder not disclosed by routine imaging techniques. The patient was proposed to undergo a surgical ovarian examination, but she was reluctant and was treated with an i.m. injection of triptorelin $(3.75 \mathrm{mg}$ ) every 28 days for three consecutive months. During this period, she experienced an amelioration of hirsutism, acne, seborrea and loss of hair. Finally, she accepted the surgical examination, and a laparotomy and oophorectomy were performed.

Pathological findings: the bilateral oophorectomy specimens consisted of the right ovary $(1.7 \times 1.3 \times$ $0.8 \mathrm{~cm})$ and the left ovary $(2.7 \times 1.4 \times 1.3 \mathrm{~cm})$, both of them with unremarkable outer surface appearance. On cross-section, the left ovary showed a $0.9 \mathrm{~cm}$ round tumour, tan in colour, located in the centre of the specimen or hilus area.

Microscopic findings: on histological examination, the Leydig cell tumour found in the hilus of the left ovary showed a solid growth, well circumscribed but non-encapsulated, of homogenous polygonal to rounded cells and a rich capillary network. The cells contained eosinophilic, slightly granular cytoplasm, occasionally vacuolated, and were disposed in a sheet arrangement. The tumour cells contained various amounts of periodic acid-schiff-positive ceroid substance. Reinke's crystalloids were not found. No mitotic figures were detected. Both ovaries showed slight signs of stromal cortical hyperplasia. The tumour cells reacted intensely to vimentin, CD99 and inhibin (M. GUIU, Barcelona, Spain). Immunostaining for cytokeratin (AE1/AE3), epithelial membrane antigen, 
desmin and S-100 protein was absent. Very few cells revealed nuclear immunopositivity with both MIB1, antibody for proliferative activity, and p53.

The patient was re-evaluated two months later; hirsutism had decreased and acne had disappeared, she weighed $83 \mathrm{~kg}$. Serum testosterone levels were in the normal range (Table 1).

\section{Discussion}

In this report, we present the case of a woman of advanced age with a rapid and severe progress of hirsutism. The first routine study performed in the patient revealed high serum levels of testosterone with normal DHEAS values, pointing to an ovarian origin. High serum levels of 17-hydroxyprogesterone were found, suggesting a non-classic deficiency of 21-hydroxylase which was confirmed with an ACTH-stimulatory test, but the past history of fertility and regular menses excluded it as the cause of the recent onset of the hyperandrogenism. An abdominal CT scan displayed discrete enlargement of the adrenal glands, probably related with the non-classic deficiency of 21-hydroxylase. Transvaginal ultrasonography and CT scan of the pelvis disclosed normal ovaries. Therefore, the source of the excess of testosterone in the patient had to originate from either a small ovarian or adrenal tumour, not visible by conventional imaging techniques, or from hyperplastic androgen-secretory ovarian cells.

It has been reported that $\mathrm{GnRH}$ analogues can inhibit the secretion of testosterone in some hyperandrogenic states of ovarian origin. Therefore, we decided to perform a test with the GnRH analogue, triptorelin. This long-acting analogue has a biphasic effect, at first stimulating the secretion of gonadotrophins, which is followed by an inhibition of both LH and FSH that lasts one month. After the administration of triptorelin, the patient presented a marked decrease in serum gonadotrophins which was accompanied by a normality of serum testosterone levels. These results seemed to indicate a gonadotrophin dependency of the hyperandrogenism in the patient, and also an ovarian origin. Moreover, the use of the GnRH analogue for three months improved the symptoms of hyperandrogenism such as seborrea, acne and hirsutism.

The appearance of the ovaries during laparotomy was normal and the pathological examination demonstrated a small hilus cell tumour.

Hilus cell tumours represent $20 \%$ of steroidogenic cell tumours of the ovaries, which in turn constitute $0.1 \%$ of all ovarian tumours. They arise from clusters of large steroidogenic cells, called hilus cells, normally found along the length of the ovaries of adult women (6-8). All aspects of their structure and function are identical to those of differentiated testicular Leydig cells. The hilus and Leydig cells cannot be distinguished by morphological criteria. Both contain a unique hexagonal array of crystals termed Reinke crystalloids that are considered to be pathognomonic, but are usually found in less than $50 \%$ of cases $(6,9)$.

Hilus cell tumours are typically small, unilateral, benign and usually found in postmenopausal women $(7,10) ; 75 \%$ of them cause virilization (11). Approximately $33 \%$ to $50 \%$ of the cases are associated with endometrial hyperplasia that has been related to high serum levels of oestradiol (12), probably due to peripheral aromatization of testosterone. An association with endometrial adenocarcinoma has also been reported $(12,13)$. Our patient presented high levels of oestradiol, but the examination of the uterus did not reveal signs of hyperoestrogenism.

Testosterone-secreting tumours of the ovaries are rare, but are well recognised causes of virilization. The diagnosis may be difficult when the tumour is too small to be disclosed by imaging techniques, and then requires hormone measurements of ovarian and adrenal veins, often with unsuccessful results. A suppressive effect of GnRH analogues on testosterone secretion by different types of ovarian tumours has been described. To our knowledge, four patients with Leydig cell tumours (1, 3-5), one with stromal luteoma (2), one with granulosa cell tumour (4) and one with hilus cell tumour (4) have been reported. In four cases the tumour was $1 \mathrm{~cm}$ in size and five cases were postmenopausal women. Testosterone levels were reduced by $50 \%$ in two patients treated with short-acting GnRH analogues, whereas a decrease to normal values was seen in the remaining patients treated with long-acting analogues $(1-5)$.

The reported inhibitory effect of $\mathrm{GnRH}$ analogues on testosterone secretion by ovarian tumours may offer a good diagnostic test. However, some caution is needed due to the fact that testosterone secretion by adrenal adenomas may be under the control of gonadotrophins (14), raising the possibility of being inhibited by $\mathrm{GnRH}$ analogues.

The inhibitory effect of the GnRH analogue on androgen secretion by ovarian tumour cells seems to be mediated by suppression of endogenous gonadotrophins. However, a direct effect of the analogue on tumour cells could also play a roll in this suppressive effect. A suppression of testosterone secretion by isolated arrhenoblastoma cells cultured in the presence of $\mathrm{GnRH}$ analogues (15), and an increase in testosterone secretion by isolated Leydig tumoral cells cultured in the presence of GnRH antagonists (5) has previously been described. The direct effect of GnRH agonists and antagonists on steroidogenesis produced by tumoral cells seems to be related to the presence of $\mathrm{GnRH}$ receptors in the cells (5).

The question of gonadotrophin regulation by testosterone in women remains unclear. In our patient, high serum testosterone levels were associated with low serum LH levels, but as serum oestradiol levels were also high, possibly due to testosterone conversion, the 
independent role of each hormone on the regulation of gonadotrophins cannot be defined.

In our patient, triptorelin produced a marked inhibition of testosterone secretion, and most of the clinical symptoms reverted during the three-months treatment trial. However, due to the lack of a diagnosis, we insisted on performing a laparoscopic examination. As in the other reports on gonadotrophic-dependent virilizing ovarian tumours, this patient also had a benign tumour.

To our knowledge, there is no experience with the long-term use of GnRH analogues in the treatment of hyperandrogenic ovarian tumours. However, a symptomatic and biochemical improvement has been described in an elderly woman treated for one year with a longacting analogue of GnRH, who had a hyperandrogenism probably due to an ovarian origin, as suggested by the hormone profile (16). In order to use it for diagnosis and for therapy, it is important to assess whether other states of hyperandrogenism due to ovarian malignant tumours and adrenal tumours are also inhibited by GnRH administration. Short-acting analogues would be useful for diagnostic purposes and longer-acting agents would be useful for treatment.

In conclusion, GnRH analogues may be of clinical benefit for diagnosis and for treatment in some benign testosterone-secreting tumours of the ovaries.

\section{References}

1 Kennedy L, Traub AI, Atkinson AB \& Sheridan B. Short term administration of gonadotropin-releasing hormone analog to a patient with a testosterone-secreting ovarian tumor. Journal of Clinical Endocrinology and Metabolism 198764 1320-1322.

2 Chico A, Garcia JL, Matias-Guiu X, Webb SM, Rodríguez J, Prat J et al. A gonadotrophin dependent stromal luteoma: a rare cause of post-menopausal virilization. Clinical Endocrinology 199543 645-649.

3 Marcondes JAM, Nery M, Mendoca BB, Hayashida SAY, Halbe HW, Carvalho FM et al. A virilizing Leydig cell tumor of the ovary associated with stromal hyperplasia under gonadotropin control. Journal of Endocrinological Investigation 199720 685-689.

4 Pascale MM, Pugeat M, Roberts H, Rouset H, Déchaud H, Dutrieux-Berger N et al. Androgen suppressive effect of GnRH agonist in ovarian hyperthecosis and virilizing tumours. Clinical Endocrinology 199441 571-576.

5 Emons G, Ortmann O, Pahwa GS, Löhrs U, Wetterling T, Dilling H et al. In vivo and in vitro effects of $\mathrm{GnRH}$ analogues on an ovarian Leydig cell tumour. Geburtshilfe und frauenheikunde 199252 487493.

6 Clerc J, Vacher-Lavenu M, Paoli V, Basin C \& Luton J-P. Tumeurs ovariennes de siége hilaire. Annales d'Endocrinologie 199051 194-201.

7 Baiocchi G, Manci N, Angeletti G, Celleno R, Fratini D \& Gilardi G. Pure Leydig cell tumour (Hilus cell) of the ovary: a rare cause of virilization after menopause. Gynecologic and Obstetric Investigation 199744 141-144.

8 Honoré LH, Chari R, Mueller HD, Cumming DC \& Scott JZ. Postmenopausal hyperandrogenism of ovarian origin. Gynecologic and Obstetric Investigation 199234 52-56.

9 Paraskevas M \& Scully RE. Hilus cell tumor of the ovary. A clinicopathological analysis of 12 Reinke crystal-positive and nine crystal-negative cases. International Journal of Gynecological Pathology 19898 299-310.

10 Sternberg WH \& Dhurandhar HN. Functional ovarian tumors of stromal and sex cord origin. Human Pathology 19778 565-582.

11 Young RH \& Scully RE. Sex cord-stromal, steroid cell, and other ovarian tumors with endocrine, paraendocrine, and paraneoplastic manifestations. In Blaustein's Pathology of the Female Genital Tract, edn 4, pp 820-854. Ed. RJ Kurman. New York: Springer-Verlag, 1994.

12 Salm R. Ovarian hilus-cell tumours: their varying presentations. Journal of Pathology 1973113 117-127.

13 Ross LD. Hilus cell tumour of the ovary with an associated endometrial carcinoma, presenting with male pattern baldness and postmenopausal bleeding. Case report. British Journal of Obstetrics and Gynaecology 198491 1266-1268.

14 Werk EE, Sholiton LJ \& Kalejs L. Testosterone secreting adrenal adenoma under gonadotrophin control. New England Journal of Medicine 1973289 767-769.

15 Lamberts SWJ, Timmers JM, Ossterom R, Verleun T, Rommerts FG \& De Jong FH. Testosterone secretion by cultured arrhenoblastoma cells: suppression by a luteinizing hormone-releasing hormone agent. Journal of Clinical Endocrinology and Metabolism $198254450-454$.

16 Parr JH, Abraham RR, Seed M, Short F \& Wynn V. The treatment of a hyperandrogenic and virilizing state in an elderly female with a synthetic LHRH agonist. Journal of Endocrinological Investigation $198811433-436$.

Received 23 September 1999

Accepted 11 February 2000 